\title{
Stefan Żywotko
}

"Nie gadaj tam o wojnie,
gadajmy o piłce nożnej"

$\bullet \bullet \bullet \bullet \bullet \bullet$

opracowanie

Szymon Beniuk ${ }^{1}$

[Wrocław]

Wrocławski Rocznik

Historii Mówionej

Rocznik IX, 2019

ISSN 2084-0578

DOI: $10.26774 /$ wrhm.235

Relacja Stefana Żywotki została zarejestrowana 28 lutego 2018 r. przez autora poniższego opracowania, w ramach projektu „100 100-latków na 100-lecie”, realizowanego przez Ośrodek „Pamięć i Przyszłość” we Wrocławiu. Celem tego projektu jest zebranie relacji biograficznych osób urodzonych przed rokiem 1923, mających teraz około stu lat, a więc rówieśników polskiej niepodległości, której okrągłą rocznicę niedawno celebrowaliśmy. Tak jak w wielu poprzednich projektach historii mówionej, tak i w tym przyjęto metodę biograficznego wywiadu narracyjnego, składającego się z trzech części - swobodnej narracji biograficznej (wywołanej pytaniem: „proszę opowiedzieć historię swojego życia”), dopytania o wybrane wątki i zadawania pytań z kwestionariusza ${ }^{2}$. Do tej pory w projekcie zarejestrowano już kilkadziesiąt relacji najstarszych Polaków, pochodzących z różnych stron kraju. W ramach kwestionariusza każdy z nich

1 https://orcid.org/oooo-0oo2-1770-4376.

$2 \quad$ Zob.: P. Filipkowski, O relacjach bytych więźniów kacetów w kontekście czasu, miejsca i sytuacji ich powstania (albo o pożytkach z historii mówionej), „Wrocławski Rocznik Historii Mówionej”, R. 2 (2012), s. 40-41. 
został zapytany m.in. o realia życia w II Rzeczypospolitej, sposoby obchodzenia w tamtych czasach świąt państwowych, wspomnienia o pogrzebie Józefa Piłsudskiego, II wojnę światową, okres tzw. Polski Ludowej i „Solidarność". Stulatkowie zostali też poproszeni o wskazanie najważniejszego według nich wynalazku i szczególnie istotnego wydarzenia w historii Polski w ciągu tych ostatnich stu lat. Podzielili się także swoim rozumieniem słowa niepodległość.

Prawie trzygodzinny wywiad biograficzny z piłkarzem i trenerem Stefanem Żywotką został sporządzony w Izbie Pamięci Pogoni Szczecin, znajdującej się przy Stadionie Miejskim im. Floriana Krygiera. To miejsce szczególne dla świadka, ponieważ z tym szczecińskim klubem związany był w latach 6o. XX w. Stefan Żywotko urodził się 9 stycznia 1920 r. w Zniesieniu - małej miejscowości, która dziesięć lat później została włączona do Lwowa. Przez całe życie, co bardzo wyraźnie przebija się w relacji, towarzyszyła mu piłkarska pasja. Od najmłodszych lat grał w piłkę nożną, występował w klubach sportowych, a później pracował jako trener. Po wojnie był świadkiem narodzin polskiego futbolu na Ziemiach Zachodnich i Północnych oraz jego współtwórcą. Pracował w szczecińskiej Arkonii i Pogoni, Arce Gdynia i Warcie Poznań, ale - jak wspomina - największe sukcesy odniósł w Afryce, gdzie prowadził algierski klub JS Kabylie (znany wcześniej pod nazwą JE Tizi-Ouzou). Mimo zdobycia najważniejszych klubowych trofeów w Afrykańskiej Lidze Mistrzów i w samej Algierii, w Polsce nie jest szerzej znany, choć - jak wspomina - tam ciągle o nim pamiętają. Wśród polskich badaczy sportu, spierających się m.in. o jego klubową przynależność z czasów młodości we Lwowie, budzi jednak wciąż żywe emocje ${ }^{3}$. Stefan Żywotko był świadkiem wielu ważnych wydarzeń historycznych, które w jego opowieści często przeplatają się ze sportem i ukazane są przez jego pryzmat.

Niniejsze opracowanie obejmuje trwającą godzinę pierwszą część relacji, w której Stefan Żywotko został poproszony o samodzielne opowiedzenie historii swojego życia. W przypisach do poszczególnych wątków swobodnej wypowiedzi zamieszczone zostały wybrane fragmenty z późniejszych etapów rozmowy, podczas których rozmówca został dopytany o szczegóły i poproszony o rozwinięcie pewnych wątków z pierwszej części ${ }^{4}$. Warto się

3 Zob. przyp.: 14.

4 Ten kolejny etap trwał około 1 godzinę i 20 min, a odpowiedzi na pytania z kwestionariusza - 35 minut. 
przy nich zatrzymać ze względu na mniej znane, „kuluarowe” historie z życia zespołów piłkarskich lat 60. i 70. XX w. W kolejnych etapach rozmowy poruszone zostały także wątki życia w międzywojennym Lwowie, mieszkających tam mniejszości narodowych, batiarów i ówczesnej piłkarskiej publiczności. Pojawił się również temat codzienności w Algierii. Edycji źródłowej świadomie poddano tylko pierwszą część rozmowy, rezygnując z pomysłu łączenia najciekawszych fragmentów z całego nagrania oraz dzielenia tematycznie tekstu. Koncepcja ta, mimo swoich niewątpliwych zalet, wiązałaby się jednak z poważną ingerencją w strukturę narracji świadka, na której zachowaniu zależało autorowi opracowania. Zachowanie rzeczywistego przebiegu swobodnej narracji pozwala śledzić opowieść w jej naturalnym kształcie i dostrzec, co i w jakim kontekście było, według Stefana Żywotki, warte wspomnienia.

Specyfiką projektu „100 100-latków na 100-lecie” jest to, że mamy w nim do czynienia z osobami bardzo wiekowymi, w różnej, nie zawsze dobrej kondycji psychofizycznej. Choć wiele z nich, tak jak i Stefan Żywotko, imponuje formą, to naturalne są występujące także i w tym wywiadzie zakłócenia, urwane zdania czy niewyraźne słowa lub chaotyczne fragmenty. W spotkaniach ze stulatkami stosunkowo często chcą też uczestniczyć członkowie rodziny, którzy próbują podpowiadać świadkowi lub wtrącać własne historie. Zdarza się, że dzięki temu świadek przypomina sobie o wydarzeniach, o które osoba przeprowadzająca wywiad by nie zapytała, gdyż nie znalazła ich śladów podczas kwerendy. Takie zaangażowanie osób trzecich może jednak w znacznym stopniu zaburzać swobodną narrację naszego rozmówcy, którą w tej sytuacji tworzy także rodzina. W nagraniu prezentowanej poniżej relacji uczestniczył syn świadka, Mieczysław Żywotko, który wielokrotnie komentował opowieść ojca, a czasami, nawiązując do pojawiających się wątków, dzielił się własnymi obszernymi wspomnieniami. Prowadzącemu wywiad nie do końca udało się też wywołać modelową swobodną narrację biograficzną: sposób sformułowania pytania otwierającego wywiad sprawił, że świadek zaczął od podzielenia się niedawnymi, bolesnymi dla niego wydarzeniami. Następnie prowadzający wywiad ukierunkował opowieść na tematy wczesnej młodości świadka. W pierwszych dziesięciu minutach kilkakrotnie padały również pytania, mające pobudzić dalsze wspomnienia, zwłaszcza w przypadku pojawienia się chaotycznej i niezbyt zrozumiałej wypowiedzi. W kolejnych minutach prowadzący ograniczał się do podtrzymywania narracji za pomocą pytania o to, co było dalej. Za zwrot w kierunku swobodnej narracji można zaś uznać 
fragment, w którym świadek, po wtrąceniu syna, mówi: „Ja chciałbym jeszcze powiedzieć o takiej rzeczy ważnej...”, po czym nastąpiła dłuższa, samodzielna opowieść Stefana Żywotki ${ }^{5}$. Swoją relację świadek zakończył na wątku przejścia na emeryturę, a próby dopytania o dalsze losy spotkały się z lakonicznymi odpowiedziami. Pytanie: „[Czy] często pojawiał się pan na meczach Pogoni [po przejściu na emeryturę]?” rozpoczęło de facto drugą część wywiadu, w której świadek rozwinął opowieści z lat 6o. i 7o. XX w., a następnie odpowiedział na inne pytania dotyczące jego życia.

Transkrypcja relacji została zredagowana językowo, tak aby tekst był bardziej czytelny. Postarano się jednak przy tym zachować styl wypowiedzi świadka i charakter języka mówionego. Zdecydowano się usunąć te komentarze syna, które były odwołaniem do jego wiedzy historycznej, a nie zmieniły toku narracji świadka lub nie spotkały się z jego reakcją. Miejsca, w których się one znajdowały, zostały oznaczone wielokropkiem w nawiasie kwadratowym. Pozostałe wypowiedzi Mieczysława Żywotki zostały zapisane kursywą oraz oznaczone inicjałami „MŻ”. Usunięto także część wypowiedzi przeprowadzającego wywiad, wyrażających zrozumienie i słuchanie rozmówcy (np. $\mathrm{mhm}$, tak), pozostawiono tylko jedno pytanie, które zostało powtórzone, gdyź świadek go nie usłyszał. Pozostałe wypowiedzi przeprowadzającego wywiad zostały oznaczone kursywą i inicjałami „SzB”. W edycji słów wszystkich obecnych na nagraniu osób pozbyto się powtórzeń i urwanych słów oraz, gdzieniegdzie, zwrotów „nie” i „no” kończących zdania. W nawiasach kwadratowych umieszczono redakcyjne dopowiedzenia.

Tytułowe zdanie: „Nie gadaj tam o wojnie, gadajmy o piłce nożnej” padło w drugiej części rozmowy (zob. przypis 37) i choć odnosi się do konkretnej sytuacji i wojennych wspomnień, które nie były głównym tematem swobodnej relacji, to cytat ten wyjątkowo dobrze oddaje mentalność świadka. Widać w nim to, co było i nadal jest najważniejsze dla Stefana Żywotki: futbol, który był jego sposobem na życie, furtką na świat, a czasami także ułatwiał międzyludzkie porozumienie.

5 W opracowaniu fragment ten zaczyna się po śródtytule Poczq̨tki polskiego sportu na Ziemiach Zachodnich i kariery trenerskiej Stefana Żywotki. 
Młodość we Lwowie ${ }^{7}$

No, urodziłem się we Lwowie. To znaczy jak ja się urodziłem, to moja dzielnica, Zniesienie, to ona była jeszcze przedmieściem miasta Lwowa. To pamiętam dokładnie, jeszcze chodniki były nie takie. Dopiero jak tę dzielnicę przyłączyli do Dużego Lwowa, to wtedy zaczęła się ta cała reforma tej dzielnicy ${ }^{8}$. Lwów, no ładne, duże miasto. Było gdzie chodzić [śmiech]. Cóż mógłbym powiedzieć dalej? Jak zwykle...

\section{SzB: Jak pan pamięta dom rodzinny?}

No, mieszkałem we Lwowie w trzech mieszkaniach. W pierwszym, tam gdzie się urodziłem. W drugim mieszkaliśmy, bo już było większe, a trzecie to mnie wyrzucili Niemcy, bo tam gdzie Żydzi mieszkali tam... ${ }^{9}$ I tak to wyglądało, że to trzecie mieszkanie, to już było blisko Ratusza i to właśnie w dzielnicy, ale to nie była żydowska dzielnica. Po prostu tak się trafiło, że zamieszkałem z tymi tam... Porozmawiałem z nimi i powiedziałem, co oni mają ode mnie [śmiech], bo zostawiłem im tam moje mieszkanie, a poszedłem do ich mieszkania... Taki był porządek rzeczy w tym czasie...

\section{SzB: A czym się rodzice zajmowali?}

Ojciec pracował w fabryce konserw Zygmunta Ruckera ${ }^{10}$. Ja [też] pracowałem w fabryce konserw Zygmunta Ruckera, tylko później [śmiech]. A znałem

6 Archiwum Ośrodka "Pamięć i Przyszłość" we Wrocławiu, sygn. AHM-801, Relacja Stefana Żywotki z 28 II 2018 r. (sporządził Sz. Beniuk).

7 Po prośbie o opowiedzenie historii swojego życia świadek zaczął od opowieści o niedawno przeżytych, bolesnych, prywatnych wydarzeniach. Fragment ten został pominięty w niniejszym opracowaniu. Relacja de facto zaczęła się od sugestii: „To może pan zacznie opowieść od dzieciństwa...".

8 W 1930 r. doszło do przyłączenia terenów podmiejskich, w tym Zniesienia, do Lwowa i stworzenia tzw. Wielkiego Lwowa. W wyniku tej decyzji administracyjnej liczba mieszkańców miasta wzrosła z 220 tys. do 316117 osób; G. Mazur, Życie polityczne polskiego Lwowa, Kraków 2007, s. 15.

9 Prawdopodobnie chodzi o niemiecką akcję przesiedlania ludności w związku z tworzeniem żydowskiego getta dla okupowanego Lwowa w 1941 r. właśnie na Zniesieniu.

10 Fabryka Konserw Zygmunta Ruckera we Lwowie została założona w 1874 r. przy ulicy Żółkiewskiej w Zniesieniu przez radnego miejskiego, aptekarza Zygmunta Ruckera 
się z Ruckerami o tyle, że prezesem klubu Czarnych we Lwowie to był właśnie doktor Zygmunt Rucker ${ }^{11}$. I ojciec tam pracował, ja rosłem, trenowałem w klubie Czarnych ${ }^{12}$. Zresztą, w ogóle chodziłem na każdy mecz. Pamiętam, jak byłem chłopcem, z tych całych piłkarzy tam było połowę Ślązaków oczywiście, w tym klubie ${ }^{13}$. No, więc oni mnie traktowali tak, jak swoje dziecko, bo ja pod bramką byłem, podawałem im piłki. Taki był początek mojej kariery piłkarskiej, właśnie w klubie Czarni. Potem, gdy dorosłem... szkoła,

(1836-1888), a po jego śmierci prowadzona przez syna Jana Jerzego Ruckera (1867-1945). Według danych z 1938 r. był to jeden z największych zakładów przemysłowych we Lwowie, który, zależnie od sezonu, zatrudniał do 600 pracowników. Przedsiębiorstwo w swojej ofercie miało m.in. przetwory mięsne i owocowe; L. Podhorodecki, Dzieje Lwowa, Warszawa 1993, S. 129, 179; The Tinned Food Factory of Zygmunt Rucker. A history of Polish business succesful formation, lia.lvivcenter.org/en/organizations/17-fabryka-rukera/ (dostęp: 18 III 2019 r.); Poznaj nasze miasto. Przewodnik po Lwowie, Lwów 1933, s. 44; Fabryka Konserw Zygmunta Ruckera S.A. we Lwowie [reklama], „Dokąd”, nr 7 z 1-20 IX 1937 r., s. 17; Fabryka Konserw Zygmunta Ruckera [reklama], „Panteon Polski”, z. 2 (6), 1925, s. 2.

11 Doktor Zygmunt Rucker (1897-1964) - wnuk założyciela fabryki i syn Jana Ruckera, działacz sportowy, społeczny, przemysłowy. W 1924 r. był przez rok prezesem Czarnych Lwów, a następnie przez wiele lat pozostawał blisko związany z jego sekcją piłkarską. W $1935 \mathrm{r}$. został mianowany prezesem honorowym klubu, pełnił także funkcję wiceprezesa zarządu; A. Gowarzewski, Wilno i Lwów wekstraklasie, Katowice 1997, s. 60; L. Rak, Infrastruktura sportowa i działalność organizacyjna I Lwowskiego Klubu Sportowego Czarni w świetle lokalnej prasy (1920-1939), „Rozprawy Naukowe AWF we Wrocławiu", nr 61 (2018), s. 105-106.

12 Chodzi o drużynę Czarnych Lwów, założoną w 1903 r., w latach 1921-1939 drugi, po Pogoni, najlepszy i najpopularniejszy klub w województwie lwowskim, biorąc pod uwagę zajmowane miejsca w tabelach rozgrywek i frekwencję na meczach; J. Goksiński, Klubowa historia polskiej piłki nożnej do 1939 r., t. 1: Regiony - branże - frekwencja, Warszawa 2013, s. 162, 483.

13 Rzeczywiście w szeregach Czarnych występowali Ślązacy. Andrzej Gowarzewski wymienia trójkę: Augustyna Drzymałę (Siemianowice), Edwarda Kocha (Mysłowice) i Teodora Mazura (Katowice), którzy mieli trafić do Czarnych po krótkiej służbie w garnizonach na wschodzie II RP. W historii lwowskiego klubu szczególnie zapisał się jednak Rochus Nastula, urodzony w Lipinach, który w latach 1927-1929 rozegrał 58 meczów i zdobył aż 56 bramek. Ustalenie, ilu śląskich piłkarzy grało w Czarnych i czy stanowili oni większą grupę niż w pozostałych lwowskich klubach, wymagałoby jednak szerszych badań; A. Gowarzewski, Encyklopedia piłkarska FUJI. Mistrzostwa Polski. Ludzie 1918-1939 r., t. 51, Katowice 2017, s. 41, 88, 127, 136; idem, Wilno i Lwów w ekstraklasie..., s. 70. 
14 Przynależność Stefana Żywotki do lwowskich klubów pozostaje kwestią sporną. Andrzej Gowarzewski twierdzi, że Żywotko, wbrew temu co podają niektóre publikacje, nigdy nie grał w Czarnych Lwów, a w latach 1935-1939 piłkarskie szlify zdobywał w dzielnicowej Zniesieńczance Zniesienie, zob.: A. Gowarzewski, Encyklopedia pitkarska FUJI. Mistrzostwa Polski. Ludzie 1945-1962, t. 53, Katowice 2017, s. 217. Czesław Giergiel w ogóle nie wspomina o Czarnych i również łączy Żywotkę z zespołem ze Zniesienia, zob.: C. Giergiel, 70 lat historii Arkonii Szczecin, Szczecin 2016, s. 18, 277. Sam Żywotko w jednym z wywiadów tak wspominał przedwojenne sposoby pozyskiwania młodych graczy przez kluby: „Wszystko zaczynało się od szkół średnich, które organizowały różne turnieje dla chłopców we wszelkich kategoriach wiekowych. W ten sposób powstała taka dzika liga, w której rywalizowaliśmy lokalnie. Z tych rozgrywek trafiało się do lokalnych klubów. Ja zostałem zawodnikiem Zniesienia Lwów”, zob.: Trener musi być najsprawiedliwszy, czyli szkolenie młodzieży okiem nestora polskiego futbolu (wywiad ze Stefanem Żywotko), „NiebywałeSuwałki.pl”, z 31 I 2019 r., https:// www.niebywalesuwalki.pl/2019/o1/trener-musi-byc-najsprawiedliwszy-czyli-szkolenie-mlodziezy-okiem -nestora-polskiego-futbolu-wywiad/ (dostęp: 18 III 2019 r.). Wersję o występach w Czarnych Żywotko powtarza jednak m.in. w publikacji poświęconej Pogoni Szczecin: „Tam [w Czarnych] też stawiałem swoje pierwsze piłkarskie kroki. Miałem kolegów w Pogoni Lwów, ale ze względu na tatę musiałem grać w Czarnych, z którymi byłem od początku do końca, czyli do 1939 roku”, zob.: K. Ufland [et al.], 70 niezwyktych historii na 7o-lecie Pogoni Szczecin, Szczecin 2018, s. 421. We wcześniejszym zaś wywiadzie wspominał: „Już we Lwowie trenowałem w Czarnych. Byłem takim kreatywnym, środkowym pomocnikiem”, a na pytanie o swój przyjazd do Szczecina po wojnie odpowiedział: „Prezes Czarnych Lwów, w których grałem, otworzył tam [w Szczecinie] fabrykę”, zob.: Niesamowite przygody Stefana Żywotki (wywiad przeprowadził Tomasz Zieliński), „Weszło.com”, z 16 V 2015 r., http://weszlo. com/2015/o5/16/niesamowite-przygody-stefana-zywotki/ (dostęp: 18 III 2019 r.). O Stefanie Żywotce pisała też szczecińska „Gazeta Wyborcza”: „Stefan Żywotko to rodowity lwowiak. Pamięta derbowe mecze Pogoń - Czarni. Jako 17-, 18-letni chłopak grał w Czarnych, ale już w lidze okręgowej (spadli w 1933 r.). Na Pogoń chodził do sekcji pływackiej, bo tylko ten klub miał basen. - Byłem większym powidlakiem niż poganiaczem - przyznaje. - Dlaczego powidlaki? Od czarno-czerwonych koszulek, które przypominały powidła. Do Czarnych miałem bliżej, bo mój ojciec był tam działaczem. Poza tym - pracowałem w fabryce konserw Zygmunta Ruckera, jednego z głównych sponsorów Czarnych", zob.: T. Maciejewski, Stefan Żywotko: Poganiaczem zostałem 

śmy na Pogoni, to rozbieraliśmy się u siebie w szatni, bo nie potrzeba było [korzystać z szatni rywali]... [śmiech $]^{16}$. [...] Dość ciekawie było, bo przy boisku Pogoni to były piękne, wysokie drzewa.

\section{SzB: Kasztanowce.}

Więc tam każde drzewo miało swój konar... Każdy konar miał swoją wizytówkę. Nie byłoby nikogo, kto by siadł komuś na tym konarze, tam gdzie [konar] miał inną wizytówkę [śmiech]. Także ta trybuna zielona, to była fantastyczna ${ }^{17}$.

w Szczecinie, „Szczecin.Wyborcza.pl”, z 24 IV 2011 r., http://szczecin.wyborcza.pl/ szczecin/1,34939,9487642,Stefan_Zywotko__Poganiaczem_zostalem_w_Szczecinie. html (dostęp: 18 III 2019 r.). Wśród tak rozbieżnych informacji najmniej prawdopodobna wydaje się wersja o występach Żywotki w Czarnych Lwów, grających od 1933 r. w lidze okręgowej (drugi poziom rozgrywkowy w II RP), gdyż był wtedy jeszcze nastolatkiem. W prezentowanej rozmowie wspomniał o zespole juniorów Czarnych, mógł więc należeć do drużyny młodzieżowej albo rezerwowego zespołu Czarnych. Możliwe też, że grał w barwach Zniesieńczanki Zniesienie, ale ze względu na swoje i rodzinne sympatie trenował niekiedy z piłkarzami Czarnych.

Chodzi o derbową rywalizację z Pogonią Lwów. Czarni i Pogoń były najpopularniejszymi drużynami w mieście przez całe dwudziestolecie międzywojenne. Jeszcze przed wybuchem I wojny światowej obydwa kluby rywalizowały o prym we Lwowie i za lepszych uważano wówczas Czarnych. W latach 20. i 30. XX w. role się odwróciły i zdecydowanie więcej sukcesów odnosiła Pogoń. Lwowskie derby obfitowały w emocje, które udzielały się również kibicom, podzielonym na „powidlaków” i „poganiaczy". Prasa donosiła niekiedy o niespokojnych meczach, wulgarnych okrzykach, czy „wyzywaniu nawet matek graczy”. Do podobnych incydentów, a czasami i do rękoczynów, dochodziło jednak również na innych stadionach. W mieście działały jeszcze m.in. Lechia Lwów, żydowska Hasmonea i Ukraina Lwów, por.: Sz. Beniuk, O pitkarskich trybunach Lwowa lat 3o. XX wieku na tamach prasy sportowej. Wybrane kwestie, „Prace Naukowe Akademii im. Jana Długosza w Częstochowie. Kultura Fizyczna", t. 17 (2018), nr 1, s. 37, 49; J. Goksiński, Klubowa historia..., s. 129-133.

Chodzi o ulicę Stryjską we Lwowie, po której przeciwnych stronach znajdowały się stadiony Pogoni i Czarnych.

W swoich wspomnieniach lwowiak Witold Szolginia pisze, że na sąsiadujące z obiektem Pogoni kasztanowce wspinali się kibice, którzy w ten sposób oglądali mecz za darmo. Mieli oni na nich swoje stałe miejsca, a poszczególne gałęzie miały być „dziedziczne”, z ojca na syna. Podobnie „zieloną trybunę” wspomina piłkarz Pogoni Lwów, Mieczysław Matyas. Z kolei skrzydłowy Cracovii, Zdzisław Skalski, twierdził, że gdy jego zespół 

dy po prostu wiedziat?

Nie, oni wiedzieli przecież... Przychodzili z flachą, sobie popili i oglądali mecz, bo bilety, trzeba przyznać, były dość drogie ${ }^{18}$. Więc na taki mecz Pogoni z kimś tam, a drzewa były bezpłatne, więc tam druga trybuna, tak zwana zielona, była bardzo ważna, bo przy tym było pełno ludzi ${ }^{19}$. To jest

grał we Lwowie z „poganiaczami”, musiał uważać na lecące w stronę przyjezdnych piłkarzy kasztany. Ta nietypowa trybuna została utrwalona na fotografiach w prasie, dostępnych m.in. w Narodowym Archiwum Cyfrowym; W. Szolginia, Tamten Lwów, t. 5: Życie miasta, Wrocław 1994, s. 131; J. Otałęga, Za lotem piłki, Kraków 2003, s. 58, 63; K. Schleyen, Lwowskie gawędy, Łomianki 2002, s. 62; Sz. Beniuk, O piłkarskich trybunach Lwowa..., s. 33-34.

18 Według wyliczeń autora tego opracowania ceny biletów na mecze pierwszoligowych zespołów w latach 30. XX w. wahały się od 1,5 do 3 zł, zob.: Sz. Beniuk, O piłkarskich trybunach Lwowa..., s. 33. „Przegląd Sportowy” (nr z 16 I 1932 r.), podsumowując sezon 1931, podawał, że przeciętny koszt biletu wynosił 1,75 zł, a rok wcześniej - 2 zł. Pracownicy fizyczni w województwie lwowskim zarabiali wówczas średnio 20,9 zł tygodniowo (kobiety 10,1 zł), a umysłowi - 61,7 zł (kobiety 38,75 zł). Mężczyzna pracujący fizycznie, idąc na mecz, wydawał więc od 7 do $15 \%$ swojej tygodniówki. Dla porównania w drugiej połowie lat 30. XX w. we Lwowie litr mleka kosztował około 20 gr, kilogram ziemniaków 8 gr, kilogram chleba żytniego 30 gr, a kilogram mięsa wołowego 8o gr; por.: Mały Rocznik Statystyczny 1939, R. 10, Warszawa 1939, S. 254-255; Rok 1931 w statystykach naczelnych władz pitkarskich, „Przegląd Sportowy”, z 16 I 1932 r., s. 5.

19 W drugiej części rozmowy świadek dopytany o zachowanie ówczesnych kibiców piłkarskich przytoczył historię z początków swojej kariery piłkarza: „Tylko pamiętam raz, już jako junior grałem w seniorach i pojechaliśmy do Drohobycza na mecz i tam coś się z tymi sędziami działo. Tak tam wpadła ta grupa tych Polaków, bo to właśnie to była polsko-ukraińska jakaś tam potyczka nasza. To tam policja przyjechała na koniach aż... Wtedy byłem w wielkim strachu, nie wiedziałem, co się dzieje [śmiech]. Młody chłopak, ja miałem 17 lat przecież, jak mnie wprowadzili do drużyny i tu nagle, ja ledwie żyję, bo to 90 minut się grało, a pod koniec meczu wpadła ta hurma na to boisko i zaczęły się tam tego... Ale policja sobie poradziła szybko, bo oni byli przygotowani na... Liczyli, że coś takiego się stanie, także zlikwidowali to. To jedno co ja pamiętam. [...] / SzB: To oprócz tej sytuacji w Drohobyczu, nie pamięta pan awantur na stadionach? / Nie, ja nie pamiętam żadnych. Raz tylko były awantury, ale to był wtedy [mecz] Polska - Rumunia bodajże, na stadionie Czarnych. To nie dlatego, że... tylko te bilety były za drogie. No to oni wszyscy, tam nie było żadnych murów, niczego, tylko siatka, no [śmiech]. Po siatce, to tam połowa kibiców już siedziała za darmo [śmiech]. Na tym meczu dokładnie pamiętam, że policja nie mogła sobie poradzić z tymi, co skakali przez siatkę na mecz z Rumunią, Polska - Rumunia we Lwowie”. 
pamiątka taka, początki piłkarskie, jakie mnie tam spotkały. No do [19]39 r. to wiadomo, jeszcze skończyłem kurs księgowo-bilansowy. W liceum, w tym handlowym ${ }^{20}$. I zacząłem pracować u Ruckera, no w tym, jak to się mówi, w rachubie ${ }^{21}$. Ojciec pracował, to mnie tam też przydzielił, ale ja tam nie mogłem wytrzymać i zgłosiłem się... pracowałem w wytwórni konserw. Trochę też puścili mnie tam do szkoły przemysłowej, gdzie uczyli mnie, co tam z tymi konserwami się robi. Ale największą przecież miałem szkołę od tych, którzy tam pracowali kilkanaście lat... I za namową przeszedłem na produkcję z księgowości [śmiech]. No i tam pracowałem dokładnie do $[19] 46 \mathrm{r}$.

SzB: Jak wspomina pan prace tam?

No ja pracowałem jako... miałem tak, sterylizacja konserw, w ogóle o całej produkcji konserwy musiałem tam dobrze wiedzieć, co [i jak]. Mieliśmy cztery takie duże kotły próżniowe i tam określona temperatura, wszystko to... Potem pracowałem na kuchni, tam gdzie się te gotowe puszki już gotowało i sterylizowało. I największą robotę właśnie miałem wtedy, bo to była ta taka kampania przed wojną ${ }^{22}$. Tak to wojsko zamówiło sobie [dostawy konserw], myśmy pracowali przez 24 godziny na dobę. Były konserwy dla marynarki, dla piechoty, wszystko było pięknie zrobione. Jak przyszli Rosjanie $^{23}$, no to, towarzysze, to zostałem fachowcem od razu [śmiech]. I pracowałem dalej w swoim dziale. A potrafiłem zrobić dżem, z różnych owoców, marmeladę [śmiech]. No, nie mówiąc o puszkach konserw mięsnych i warzywnych. Także stałem się wielkim tam znawcą i pracownikiem, jak to się mówi, ekstra. Gdzie trzeba było, to ja już tam mogłem to robić. To pracowałem, pamiętam, za czasów tych niemieckich, to pracowałem od 16.00 do 6.oo rano. Bez przerwy, żadnego tam, tydzień taki, nie taki. Nie, bo mnie tam Szwab wsadził i miałem tam siedzieć, i musiałem robić.

20 Chodzi o Liceum Handlowe Towarzystwa Liceum Handlowego przy ul. Skarbkowskiej 39 we Lwowie, zob.: Księga adresowa Małopolski: Lwów, Stanisławów, Tarnopol z informatorem m. stot. Warszawy, województwa krakowskiego, pomorskiego, poznańskiego i śląskiego, R. 1935/1936, Kraków 1936, s. 35-36; Lwów. Przewodnik orientacyjny z planem i 8 ilustracjami, Lwów 1930, s. 17.

21 Chodzi o księgowość fabryki.

22 Chodzi o wzmożoną produkcję przed spodziewaną w 1939 r. wojną.

23 Okupacja Lwowa przez Armię Czerwoną rozpoczęła się 23 IX 1939 r. 


\section{Wojna}

SzB: Ijak pan wspomina wybuch wojny?

No pierwsza okupacja to była Związku Radzieckiego - Zdradzieckiego. Druga to była niemiecka, a trzecia znowu. I w tej trzeciej to już ja dostałem powołanie do wojska.

SzB: Który to byt rok?

To był 19[46]...

MŻ: Jak [194]6?

$[\ldots]$

Wojna wybuchła z Niemcami w [19]41 r. $^{24}$ [...] No. I ja dostałem... potem powstała ta polska armia ${ }^{25}$. [...] I do polskiej armii zostałem powołany...

MŻ: To nie [194]6 byt. W [194]6 to się już wojna skończyła.

No.

SzB: Może [19]4.4?

MŻ: Tak, raczej tak.

[19]44. W [19]46 to już byłem w Szczecinie.

MŻ: No wtaśnie, dlatego mówię, że nie [194]6.

Pomyliło mi się, te czasy. W każdym razie pracowałem. Wojna, to fabrykę oczywiście Niemcy zbombardowali od góry do dołu. Fabryki nie było. Byłem bezrobotnym. [...] I to wtedy tam skończyłem pracę [w fabryce], bo nie

24 Chodzi o atak III Rzeszy na ZSRR w czerwcu 1941 r. Lwów Niemcy zajęli 30 VI 1941 r.

25 Chodzi o 2. Armię Wojska Polskiego, zob. przypis 29. 

tam w spółdzielni mnie przyczepili.

\section{MŻ: Rosyjski, nie?}

No, ale dostałem powołanie, mobilizacja i ja zostałem powołany do armii. I poszedłem do swojego prezesa ${ }^{27}$ i mówię: „No, do wojska mnie biorą”. To mnie dał o tydzień [odroczenia], jak to się mówi, przedłużył. Drugi tydzień i jeszcze trzeci tydzień to samo. A byłem razem z Kaziem Górskim ${ }^{28}$ w tej przetwórni, gdzie myśmy tam wisieli na etacie, bo my przecież nie pracowaliśmy w tej spółdzielni. I ja dostałem powołanie, no, bo mobilizacja i musiałem się zgłosić do tego... Zgłosiłem się, dostałem przydział do armii i koniec. [...] trzeba było spakować plecak i jechać do wojska.

MŻ: Bo to jeszcze byto tak, że zanim powstata ta 2 Armia $^{29}$, to ludzi tam miejscowych powotywali normalnie do Czerwonej Armii ${ }^{30}$.

No.

26 Prawdopodobnie mowa tu o Spartaku Lwów, związanym z branżą spółdzielczą, utworzonym w czasie okupacji Lwowa przez ZSRR; R. Stefanik, Futbol w cieniu komitetów. Piłka nożna a władza w województwie szczecińskim w latach 1945-1989, Szczecin 2016, s. 25.

27 Osoba bliżej nieznana.

28 Chodzi o Kazimierza Górskiego (1921-2006), piłkarza RKS-u Lwów, Spartaka i Dynamo Lwów oraz Legii Warszawa, trenera kilku klubów w Polsce i Grecji. Zasłynął jako selekcjoner reprezentacji Polski, z którą zdobył złoty medal igrzysk w Monachium i srebrny w Montrealu oraz brązowy na Mistrzostwach Świata w 1974 r.; A. Gowarzewski, Encyklopedia piłkarska FUJI..., s. 57.

29 Chodzi o sformowaną w sierpniu 1944 r. 2. Armię Wojska Polskiego, której dowodzenie powierzono gen. Karolowi Świerczewskiemu.

30 W 1939 r. Związek Sowiecki zajął wschodnie tereny II RP, następnie po sfałszowanych wyborach powołał Zgromadzenia Ludowe Zachodniej Ukrainy i Zachodniej Białorusi, które zgłosiły akces okupowanych ziem do ZSRR. W konsekwencji doszło do aneksji tych terenów, a mieszkańcy Kresów Wschodnich stali się obywatelami Związku Sowieckiego, co umożliwiało powoływanie m.in. Polaków do Armii Czerwonej. 
MŻ: Także ojciec akurat byt rocznik taki, że rok później [miat iść], bo jego

kolega [19]19 byt, to poszedt do Czerwonej Armii i ślad po nim zaginat, no nie? A ojciec już poszedt do tej armii polskiej, tej drugiej, która utworzono na terenie Zwiazku Radzieckiego.

Tak. Także nasza ta armia ze Lwowa do Przemyśla, bo tam była ta granica, to szła na piechotę. A pierwszy transport kolejowy to właśnie my jechaliśmy już do Hrubieszowa, czyli [najpierw] do Łucka, a z Łucka na piechotę już szliśmy do Hrubieszowa. Ja się do... pułk kawalerii i konie, no [śmiech]. I z końmi miałem [wcześniej] no tyle wspólnego, że jechałem z mamą, gdzieś tam na wakacje, to konie widziałem, i tam się zabawialiśmy trochę z końmi, jako dziecko, jako chłopiec [śmiech]. A tu nagle...

\section{SzB: I co byto dalej, jak pan byt w tej armii?}

No to jak to w wojsku. Ale udało mi się dobrze, bo zostałem pisarzem w szwadronie, bo w kawalerii, to jest szwadron, nie? To była druga osoba po dowódcy, taki pisarz w szwadronie. Dlatego, że ja znałem język rosyjski, bo pamiętam, że $\mathrm{w}$ [19]31, nie, w [19]39, w [19]41 r. to nas, tych poborowych, zwalniali dwa razy w tygodniu na naukę języka rosyjskiego. No ja się o tyle, że się nauczyłem i pisać, i ten... to mnie uratowało. No, bo ja dostałem się do kancelarii szwadronowej i byłem pisarzem, bo znałem właśnie ten rosyjski język w mowie i w piśmie. A był taki dobry ten dowódca szwadronu ${ }^{31}$, że jego nic nie interesowało, co ja robię, nie robię. Tak mi się świetnie żyło w Hrubieszowie, w tym wojsku. Z końmi miałem tylko do czynienia, ja wiem, z miesiąc niecały, a potem to już siedziałem w kancelarii. Jemu tam pomagałem, jak trzeba było coś przetłumaczyć z polskiego na rosyjski. Mieszkaliśmy już w takim budynku oficerskim, a ja byłem zwykły kapral, no [śmiech]. Potem, jak to wojsko, zawsze coś się zmienia. Naszą dywizję, tę warszawską, kawalerii ${ }^{32}$ przerzucili pod Warszawę, jak tam były te boje ${ }^{33}$, a ja zostałem jeszcze. Tam trzeba było zlikwidować tę całą historię gospodarczą. Mieliśmy tam jednostkę, która odbierała przecież obrok dla koni, dla wojska i z nimi wyjechałem.

\footnotetext{
31 Osoba bliżej nieznana.

32 Zapewne chodzi o 1. Warszawską Samodzielną Brygadę Kawalerii.

33 Zapewne chodzi o powstanie warszawskie (1 VIII - 2 X 194.4 r.).
} 


\section{Ziemie Zachodnie}

Wyjechałem gdzie? No, oni usadowili naszą tę brygadę ${ }^{34}$ w Koszalinie. I jako armia wylądowaliśmy tam, w Koszalinie, tak. Końcówka wojny już to była, jak jeszcześmy tam gdzieś się pod tę granicę szwendali, ale to już nie była wojna, tylko przesuwanie się po prostu z jednego miasta, z jednego okręgu do drugiego. I tak zostałem w armii do [19]46 r.

SzB: I co byto dalej?

No, w [19]46 r. akurat ten inżynier, u którego pracowałem we Lwowie ${ }^{35}$, mój szef produkcji konserw, dostał przydział organizacji w obwodzie szczecińskim. Dostał przydział na zorganizowanie filii, tej przemysłu konserwowego w Szczecinie. No i dowiedział się, że jestem w wojsku. A [wcześniej] bardzo współpracowałem z nim, jeżeli chodzi o produkcję, i on napisał pismo do generała i generał mnie zwolnił z wojska. Tak prosto z wojska przyjechałem do Szczecina. Byliśmy najpierw w Koszalinie, a z Koszalina przyszli tu gdzieś, pod Trzebiatów, no. Ta jednostka... sztab dywizji. No i tak zostałem szczecinianinem w [19]46 r. [śmiech]. I znowu [trafiłem do] przemysłu tego konserwowego. I z tym inżynierem swoim mówimy: „Jedziemy zobaczyć te poniemieckie zakłady przemysłu konserwowego", bo on był tym zainteresowany. No i pojechaliśmy oglądać, to tylko były [z fabryki] same mury [śmiech]. Bo... żadnych maszyn, niczego, nawet wyłączniki ze ścian powyrywane. I mówię: „Co pan, [co] my tu będziemy robić?”. No nic, założyliśmy chyba te z trzy sklepy mięsne, tam handlowało się mięsem wtedy bardzo dobrze. Tylko to dla mnie to nie było nic ciekawego. Na mięsie to się znałem o tyle, o ile, żeby wiedzieć, czy jest dobre czy niedobre, czy smakuje.

\section{SzB: Czyli zamieszkat pan w Szczecinie, zaczą pan pracę...}

Zamieszkałem w Szczecinie, sprowadziłem rodziców. Tak, ostatnim transportem, który wyrzucili ze Lwowa, tych lwowiaków, co akurat rodzice dostali się do [niego]... Mieszkaliśmy tam w centrum miasta, potem dostałem mieszkanie, bo w centrum miasta to nie można było zamieszkać, stare,

34 Zapewne chodzi o 1. Warszawską Dywizję Kawalerii, która została sformowana na bazie 1. Warszawskiej Samodzielnej Brygady Kawalerii w 1945 r.

35 Osoba bliżej nieznana. 
już, na Pogodnie ${ }^{36}$, było przyzwoite mieszkanie, dostałem mieszkanie i tak zostałem $^{37}$.

\section{SzB: Zaczą pan prace, co byto dalej?}

W Szczecinie, no, różnie to było. Początki były dobre, potem było trudno, potem znowu było dobrze. W zależności od tych różnych gospodarczych zawirowań, to raz było dobrze, raz było źle. No... Trzeba było żyć. [...]

36 Chodzi o osiedle położone w zachodniej części Szczecina.

37 Temat przyjazdu na Ziemie Zachodnie powrócił w drugiej i trzeciej części wywiadu: „SzB: Chciałbym jeszcze zapytać o Szczecin. Jak pan tutaj się przeprowadzit po wojnie, czy poczut pan, że to jest pana miasto, pana dom? / Nie, skąd. Ja mieszkałem razem z Niemcami, no. Jak przyjechałem, to dostałem właśnie ten przydział na Jagiellońską i tam mieszkałem z Niemcami. Człowiek tak jak był przez nich prześladowany, to myślał... [Jakbym] Szwabom się dostał, to bym... A potem ich karmiłem, no bo taka była ta właśnie, ta Szwabka gdzieś [w] wieku mojej matki, to człowiek patrzył na tych ludzi i żal było. No, bo oni też byli bardzo gnębieni, to nie było tak łatwo im tutaj żyć, jak się tu, w Szczecinie, to wszystko wymieniało. Tutaj pamiętam ich jeszcze zwozili, bo ta ulica od Poniatowskiego do torów kolejowych, te bloki wszystkie, to były zadrutowane. Tam był obóz, ten przejściowy, i oni tych Niemców, z całego tego województwa sprowadzali tutaj. Tu przetrzymywali i robili te transporty i wywozili do Niemiec. Także... A potem mieliśmy przyjazne stosunki. Wprowadzano to już tak po tym politycznym, tam tym, przejścia [graniczne] i tak dalej, co się stało z granicami tego... To pierwszą drużyną [piłkarską] zagraniczną to byli Niemcy, tutaj graliśmy przeciwko Niemcom, nie? No jak ten Niemiec się tam tłumaczył z tej wojny... Ja mówię: «Nie gadaj tam o wojnie, gadajmy o piłce nożnej» [śmiech], bo oni się ciągle tłumaczyli z tego, że oni nie są hitlerowcami i że to, no tak było i tego... i oni musieli tam... Tłumaczył się taki ten trener ich. [śmiech] Ja mówię: «Przestań gadać tak...». Potem byliśmy kolegami, bo on tam prowadził tę drużynę w Niemczech, to dwa razy byłem też u niego tam, na tych towarzyskich takich meczach piłkarskich, przecież to było dobrze. [...] I ta aglomeracja szczecińska była różna, bo tutaj ludzie z dużych miast byli i z zabitych wsi. To pamiętam, że gdzieś na ulicy Jagiellońskiej, faceci trzymali węgiel w wannie, w łazience, bo im się nie chciało do piwnicy iść. [śmiech]". 


\section{Początki polskiego sportu na Ziemiach Zachodnich i kariery trenerskiej}

Ja chciałbym jeszcze powiedzieć o takiej rzeczy ważnej, bo w Koszalinie, tuż po wojnie, zorganizowano pierwsze Igrzyska Ziem Odzyskanych i Północnych, sportowe ${ }^{38}$. I to rzeczywiście zadziałało fantastycznie. Tam była piłka nożna, koszykówka, lekkoatletyka, wszystko i... To wszystko się mieszało. Ja, jako kawalerzysta, od razu zrobiłem drużynę piłkarską. Myśmy tam grali o puchary. I tam poznałem właśnie wielu działaczy sportowych, bo to każda ta jednostka, te spółdzielnie, te różne zakłady, które tam były, to miały swoje drużyny i wszystko. I w ten sposób poznałem działaczy piłkarskich w Szczecinie [śmiech]. Jak skończyłem to wojsko, przyjechałem do Szczecina i pierwszego kogo spotkałem, właśnie jednego z tych, którzy grali, brali udział w tym turnieju, tych Ziem Odzyskanych. I on mówi do mnie: „Chodź, pojedziemy do lasku, bo tam jest mecz piłkarski”. A ja akurat nie wiedziałem, jak się po Szczecinie poruszać, bo byłem chyba ze dwa, trzy dni. I on mnie wziął w samochód i pojechaliśmy. Oczywiście pierwsze boisko, jakie zobaczyłem, w Lasku Arkońskim ${ }^{39}$. No i piłka to jest straszny nałóg. No i tak trafiłem do [klubu ${ }^{40}$, tam grał wtedy Fortuński ${ }^{41}$, potem był

38 Tuż po wojnie na tzw. Ziemiach Odzyskanych organizowano wiele imprez, które, oprócz wymiaru sportowego, miały też charakter propagandowy i podkreślały polskość tych ziem; por.: R. Stefanik, op. cit., s. 34-35; M. Ordyłowski, Rozwój kultury fizycznej na Ziemiach Odzyskanych w pierwszych latach po II wojnie światowej, [w:] Z dziejów sportu na Ziemiach Zachodnich i Pótnocnych Polski po II wojnie światowej, red. J. Maliniak, P. Sroka, G. Strauchold, Wrocław 2014, s. 14-15.

39 Park Leśny Arkoński (znany jako Lasek Arkoński) - obszar rekreacyjny, położony w północno-zachodniej części Szczecina, na którego terenie znajduje się stadion wybudowany jeszcze w latach 20. XX w. Po wojnie obiekt ten stał się własnością klubu Arkonia Szczecin; C. Giergiel, op. cit., s. 15.

40 Prawdopodobnie chodzi o Milicyjny Klub Sportowy Szczecin, zarejestrowany w marcu 1946 r., od czerwca funkcjonujący jako Milicyjne Stowarzyszenie Sportowe, a od końca lutego 1948 r. jako Gwardia (Giergiel podaje, że Milicyjny KS Szczecin już w połowie 1947 r. zmienił nazwę na Gwardia Szczecin). Klub podlegał Ministerstwu Bezpieczeństwa Publicznego; R. Stefanik, op. cit., s. 351; C. Giergiel, op. cit., s. 19.

41 Chodzi o Stanisława Fortuńskiego (1912-1989), wiceprezesa Milicyjnego KS, późniejszego opiekuna klubu i sekcji piłkarskiej Arkonii Szczecin, prezesa Okręgowego Związku Piłki Nożnej, członka Komitetu Wojewódzkiego PZPR, a także dyrektora Stoczni Szczecińskiej; R. Stefanik, op. cit., s. 56, 88, 351; Stanisław Fortuński - dane osoby z katalogu kierowniczych stanowisk partyjnych $i$ państwowych PRL, Biuletyn Informacji Publicznej Instytutu Pamięci Narodowej, www.katalog.bip.ipn.gov.pl (dostęp: 12 II 2019 r.). 
szefem gdzieś tam w Komendzie Wojewódzkiej. I mnie nakręcili, nakręcili, jeszcze zostałem instruktorem sportowym w tym Zrzeszeniu "Gwardia”42. Zajmowałem się już dokładnie sportem i piłką nożną. Grałem tam jeszcze do 31. roku życia. Do Szczecina ściągnąłem "Muchę” Czyżewskiego ${ }^{43}$, którego znałem z klubu we Lwowie, oczywiście. On się zgodził, przyjechał tutaj z rodziną i był naszym trenerem. Ja się koło niego tam zacząłem kręcić. Nawet zrobiłem jakieś pierwsze początki, to był kurs instruktora czy pomocnika instruktora. W każdym razie od niego się nauczyłem wiele, no bo on był po CIWF-ie ${ }^{44}$, jeszcze wtedy, on szkołę przed wojną skończył. Także dobrze nam się współpracowało.

\section{SzB: I grat pan w Arkonii Szczecin...}

Tak, grałem w Arkonii do 31. roku życia ${ }^{45}$. Potem, tak jak mówię, no więcej pomagałem Czyżewskiemu, jak sam grałem, bo to jeden człowiek to sobie nie mógł poradzić. Także związek wysłał mnie do Krakowa. Tam zrobiłem pierwszy kurs instruktorski, w tym Krakowie. [...] To był który rok?

\section{MŻ: Pięćdziesiąty któryś... już nie pamiętam.}

No, w każdym razie dość wcześnie, bo w [19]52 no, tam zrobiłem ten kurs instruktorski. I nagle okazało się, że w Krakowie organizują kurs już trenerski.

42 Pod koniec 1948 r. władze polskiego sportu ogłosiły reorganizację klubów sportowych, które od tej pory miały podlegać zrzeszeniom branżowym. Milicja oraz służby bezpieczeństwa weszły w skład Zrzeszenia Sportowego „Gwardia”; R. Stefanik, op. cit., s. $40-41$.

43 Chodzi o Zygmunta Jana Czyżewskiego ps. „Mucha” (1910-1998), piłkarza m.in. Czarnych Lwów, reprezentanta Polski w hokeju na lodzie, trenera Arkonii, Pogoni, wrocławskich zespołów Pafawag, Ślęza oraz Śląsk, działacza PZPN i PZHL, pracownika AWF Wrocław; A. Gowarzewski, Encyklopedia piłkarska FUJI..., s. 35.

44 Chodzi o Centralny Instytut Wychowania Fizycznego (CIWF) utworzony w 1929 r. w Warszawie, a w 1938 r. przekształcony w Akademię Wychowania Fizycznego Józefa Piłsudskiego (AWF Warszawa).

45 Wówczas była to jeszcze Gwardia Szczecin, a klub ten, w wyniku fuzji, przyjął nazwę Arkonia dopiero w 1958 r., już po zakończeniu kariery piłkarskiej Żywotki i rozpoczęciu trenerskiej. Tradycyjnie za datę założenia klubu Arkonia uznaje się 3 III 1946 r., kiedy to powstał Milicyjny KS Szczecin; C. Giergiel, op. cit., s. 16, 48. 
A znałem Koncewicza ${ }^{46}$, bo on był wtedy szefem wyszkolenia w Polskim Związku Piłki Nożnej. I od razu mnie tam, jako jednego z tych lepszych instruktorów, z tego kursu pierwszego, no powołał mnie. Także trzy miesiące siedziałem w Krakowie i robiłem kurs trenera drugiej klasy. Zrobiłem trenera [drugiej klasy] $]^{47}$. Tam był Górski ${ }^{48}$, ale cała plejada tych najlepszych, najlepszych w tym czasie reprezentantów piłki nożnej w Polsce, na tym kursie się znalazło. Nas było prawie pięćdziesiąt osób. Trzy miesiące siedziałem tam. To było już naprawdę bardzo ciężko [śmiech]. Ale zrobiliśmy ten kurs i dostałem dyplom trenera drugiej klasy. Wróciłem, zacząłem w Gwardii normalnie trenować ${ }^{49}$. To doszło do tego, że oni mi powiedzieli: „No, jesteś instruktorem, płacimy ci za to, że jesteś instruktorem, no to...”. A ja dostawałem już w Gwardii dodatkowe pieniądze za treningi piłkarskie. No to oni mnie tu obcięli. Było tam też ileś tam tych złotych, to ja mówię im: „Jak mi nie będziecie płacić, to ja przecież nie będę trenował, no”. I w ten sposób znalazłem się w Stali Stocznii ${ }^{50}$. Powiedziałem: „Do widzenia". I w Stali Stoczni zacząłem swoją karierę trenerską. Pamiętam, że ja zostałem powołany właśnie do Wrocławia na ćwiczenia wojskowe, trzy miesiące, a oni w międzyczasie się ożenili ze Stocznią [śmiech]. Bo ja pojechałem ze Stoczni jako stoczniowiec na ten [na ćwiczenia wojskowe]. [...] A Stocznie połączyły się z Gwardią i stworzyli Arkonię ${ }^{51}$. Ja przyjeżdżając do Szczecina, trafiam nie do Stoczni, tylko trafiam do Arkonii [śmiech].

46 Chodzi o Ryszarda Koncewicza (1911-2001), piłkarza m.in. Lechii Lwów, trenera Polonii Bytom, Ruchu Chorzów, Legii Warszawa i reprezentacji Polski. W PZPN-ie był szefem Rady Trenerów i zajmował się szkoleniami; honorowy członek tej organizacji; A. Gowarzewski, Encyklopedia piłkarska FUJI..., s. 89.

47 Stefan Żywotko ukończył kurs trenerski drugiej klasy z wynikiem bardzo dobrym w grudniu 1952 r., a od 1960 r. był już trenerem pierwszej klasy; R. Stefanik, op. cit., s. 204.

48 Por.: K. Górski, S. Grzegorczyk, J. Lechowski, Sekrety trenera Górskiego, Warszawa 1992, s. 63.

49 Chodzi o Gwardię Szczecin (zob. przypis 45).

50 W 1957 r. powstał klub sportowy Stal Stocznia, który wywodził się z utworzonego w 1950 r. koła sportowego „Stal” przy Stoczni Szczecin, które to z kolei zostało sformowane na bazie klubów ZKS Metalowiec oraz Stoczniowiec (1948 r.); R. Stefanik, op. cit., s. 215,363 .

51 Arkonia Szczecin powstała w styczniu 1958 r. w wyniku fuzji Stali Stocznia i KS Chrobry (dawna Gwardia, która połączyła się w styczniu 1957 r. z KS Budowlani). Arkonia kontynuuje tradycje utworzonego w 1946 r. Milicyjnego KS-u (późniejsza Gwardia i Chrobry); R. Stefanik, op. cit., s. 215, 351; C. Giergiel, op. cit., s. 44-45, 48. 

stali bez trenera. A ja akurat z pełnią energii i sił z Krakowa przyjechałem z głową taką z teorii piłki nożnej [śmiech]. I zacząłem pracę w Gwardii jako trener $^{53}$. Doprowadziłem ich do pierwszej ligi. Spadłem z pierwszej ligi, bo pan sekretarz Komitetu Wojewódzkiego pojechał na... Bo myśmy weszli do pierwszej ligi z szumem, bo dość było wesoło, bo i Pogoń wchodziła, i my wchodziliśmy $^{54}$. Ta konkurencja z Pogonią zaczęła się od samego początku. Także jak on [sekretarz Komitetu Wojewódzkiego] pojechał gdzieś na wycieczkę do Czech i z Czech przywiózł trenera ${ }^{55}$. No i powiedział, żebym ja z nim trenował. A ten Czech to była noga. On w ogóle nie wiedział... teoria piłki nożnej to dla niego nie istniała. On tam sobie gdzieś trenował jakąś tam drużynkę. No więc jak towarzysz sekretarz przywiózł takiego trenera, no to trzeba było jemu zrobić miejsce i w ten sposób zostałem odsunięty, delikatnie mówiąc. I ten Czech z tą Gwardią tak trenował, że oni spadli od razu do drugiej ligi, bo ja ich wprowadziłem do pierwszej, a on ich wprowadził do drugiej [śmiech]. No trochę pracowałem w Poznaniu ${ }^{56}$. Poznań

52 Okręgowy Związek Piłki Nożnej odgrywał rolę lokalnych struktur PZPN. Kluby w Szczecinie podlegały OZPN Pomorze Zachodnie.

53 Zob. przypis 45 .

54 Chodzi o Pogoń Szczecin.

55 Osoba bliżej nieznana.

W latach 1965-1970 Stefan Żywotko, zanim jeszcze wyjechał do Poznania, był trenerem Pogoni Szczecin. Tak do tego okresu odniósł się w drugiej części wywiadu: „Bywam, bywałem jak najbardziej [na meczach Pogoni Szczecin po przejściu na emeryturę]. No to była ta grupa tych piłkarzy, którzy mnie uwielbiali, bo na moje urodziny to mi przysłali pozdrowienia od piłkarzy grupy 6o. No i przysłali mi bukiet kwiatów z życzeniami od piłkarzy rocznika [19]6o. To ja wtedy tam tą Pogoń, jak przyszedłem, to w ogóle tam zrobiłem czystkę, bo trochę tam wrogów sobie zrobiłem. I tą drużyną wszedłem z powrotem do pierwszej ligi i to takiego tego, jak tego [Zenona] Kasztelana... No przecież to miałem tam perełki, bo ja z nim... niezależnie od wszystkiego to ja zawsze miałem 6-8 młodych juniorów, z którymi ja trenowałem. I oni byli brani pod uwagę na każdy obóz szkoleniowy. Także ten zawodnik młody, dwudziestolatek, to on już był wdrożony do systemu. Tak, już wiedział, jak trzeba grać na tej pozycji i grali już. Jak tylko był towarzyski mecz, to ja połowę juniorów pchałem. Także tą drużyną sześćdziesiątą to stworzyłem z tych młodych chłopców, no. Ja pamiętam tego właśnie, tylko wprowadziłem go [Kasztelana] na mecz... po meczu w tym, w Krakowie, myśmy przegrali 2:o ze starą tą swoją drużyną. No to ja przyjechałem do Szczecina i kogo ja dam - trzydziestopięciolatka zmienię jego sens 
mnie tam kaperował dość długo w poznańskiej Warcie ${ }^{57}$. Ale tam znowu pan prezes przyszedł do mnie z karteczką ze składem drużyny przed meczem. Ja do niego mówię: „Panie inżynierze, no przecież wiadomo, że tam mamy w umowie napisane jak i co. Jakie są moje obowiązki”. „Nie, tutaj jest rada starszych... - bo oni tam sobie zrobili [radę] - rada starszych ustaliła, że taki będzie skład w Poznaniu” [śmiech]. No ja mówię: „Jak tak, jakby pan powiedział, jakbym ja poszedł do pana kuźni - bo on był szefem kuźni - i panu poprzestawiał, pana tych kowali?”. On mówi: „No wie pan, panie trenerze, że jest [niezrozumiałe]". Bo on był taki młody człowiek i słuchał tych starych, byłych mistrzów, bo oni się ciągle chwalili w tej Warcie, że oni byli mistrzami Polski. W dwudziestym którymś tam roku, nie ${ }^{58}$ ? [śmiech] No i... to ja powiedziałem do niego: „No to niech pan idzie na moje miejsce, ja jadę do domu" [śmiech]. I pojechałem do domu i zostawiłem Wartę.

\section{SzB: Który to byt rok?}

No...

MŻ: Osiemdziesiąty czwa... [198]3 chyba.

No, w każdym razie, tam prowadziłem do trzeciej ligi... No, ale jak tak wyszło, no to ja pojechałem do domu i oni mi przysyłali pieniądze do domu.

myślenia... Jeżeli chodzi o piłkę wszystko po kolei wprowadzałem. I ten [Kasztelan] strzelił trzy bramki, startujący junior w pierwszej drużynie. To była sensacja. Myśmy grali wtedy z Wałbrzychem. Trzy bramki strzelił junior, [śmiech] którego wprowadziłem. To się otworzyły bramy do wszystkich, bo ci chłopcy grali, naprawdę dobrze grali. Ale oni byli trzymani, bo to juniorzy, no. A stara sitwa, jak zwykle, po meczu to bankiety mieli, byli zmęczeni, z trzy, cztery dni. To potem grali, to się... Tak grali, jak im sił starczało, no. A znałem dokładnie wszystkie te [historie]... bo człowiek żyjąc w tym samym mieście, dokładnie wie wszystko, co się dzieje tu i tam. Niektórzy zawodnicy z tej drużyny przychodzili mi opowiadali różne rzeczy. [...] Ale jak tam bankietowali, jak ja kiedyś spotkałem, to oni nie kupowali butelkę, dwie, tylko skrzynkę od razu".

57 Stefan Żywotko prowadził Wartę w latach 1972-1975 i 1977. Dane z serwisu gromadzącego statystki piłkarskie FootballDataBase.eu, www.footballdatabase.eu/en/ player/details/122406-stefan-zywotko (dostęp: 13 II 2019 r.).

58 Warta Poznań zdobyła Mistrzostwo Polski w 1929 r., ponownie po ten tytuł sięgnęła w roku 1947. 

podpisywali". I on nawet nie [sprawdził]. No, a przyszła ta kontrola z Głównego Komitetu Kultury Fizycznej, pytają się: „A gdzie trener, koordynator, nie?" [śmiech]. A oni nie wiedzieli, co mówić. Telefon, ja przyjechałem i pytają się: „Co pan robi?” - ten mówi z Głównego Komitetu Kultury Fizycznej ${ }^{59}$. Ja mówię: „No, jeżeli tak sobie życzy ten zarząd, to ja tak robię, jak oni chcą". No i kazali mi tam robić dokumenty na instruktora. Ja mówię: „Każdy instruktor powinien sam sobie pisać swoje plany pracy i jak prowadzi te zajęcia”. I przyszli do mnie znowu, ja ich zostawiłem i powiedziałem: "Ja takiej roboty się tu nie podejmuję". Ale przyszli do mnie znowu z Arki, z Gdyni. A żona akurat tam miała rodzinę w Gdańsku. Także namówili mnie na Arkę, do Gdyni ${ }^{60}$.

59 Główny Komitet Kultury Fizycznej - utworzony w 1950 r. centralny organ zajmujący się sportem i turystyką w PRL.

60 Stefan Żywotko trenował Arkę Gdynia w latach 1975-1977. Szerzej odniósł się do tego, po wtrąceniu syna, w drugiej części wywiadu, przytaczając kulisy życia codziennego zawodników: „MŻ: W Arce ojciec miat takiego byłego zawodnika Arkonii, fantastyczny talent, nazywat się [Waldemar] Tandecki. To niestety miat te problemy i z reguty, jak po meczu miat balange, to $w$ poniedziatek miat specjalne zajęcia treningowe... Że to wszystko co wypit, to oddawat [śmiech]. Przewroty ojciec kazat mu robić. Jak przyszedt na trening i byto widać, że jest nieświeży. / W poniedziałek to zrobiłem dalszy trening o 8.oo rano [śmiech] żeby jeszcze był na fali, nie? I potem mówił: «No co, ile?». «No tak jedną długość przewrotami, a potem wracasz z powrotem truchtem». No, to po takich dwóch tych przewrotach, to tam wyrzygali to wszystko, co wypili [śmiech]. Ale będąc tam na zaproszenie do Arki, to ten jeden z tych zawodników przyszedł do mnie i powiedział: «Panie trenerze, dziękuję panu, bo pan ze mnie zrobił człowieka». Satysfakcja, ożenił się... / MŻ: [Stefan] Kliński. To byt świetny obrońca... / Mówi tak: «Mam dziecko, mam żonę, mieszkanie. Dziękuję panu za to, co pan dla mnie zrobił». A to był taki pijaczek śląski... [śmiech] Jak oni tam prowadzili tę Arkę, to ja nie chcę mówić, bo w każdym razie, lokal dla Arki to taka buda, gdzie chlali, lali pod ścianami nawet. Okropne... Jak zaprowadzili tam pierwszy obiad, jak ja przyszedłem, jak ja powąchałem to wszystko, to ja mówię: «Co... co to jest... to?» [śmiech] I w najlepszym lokalu w Gdyni zamówiłem obiady i [śmiech] kolacje dla zawodników. To tam elegancko, stoliki, tego... Ja mówię: «Uczcie ich kultury, żeby nie lali pod murem, tylko żeby wiedzieli, gdzie są». I ten jeden właśnie z tych [zawodników] mówił, że ja z niego zrobiłem człowieka, bo on lubiał popić. I on zawsze przychodził o te pół godziny wcześniej do restauracji. Ja tak zauważyłem i kiedyś specjalnie przyszedłem, patrzę, a on już ma talerz rosołu na stole, a stoi już seta [wódki] obok tego [śmiech]. Jak on mnie zobaczył, to on ten kielicha siuuu [wlał] do tego rosołu [śmiech]. A ja nic nie mówię, że ja widziałem, tylko mówię: «Cześć Stefan, co słychać, jak to tego...?» A on tak się 
kręci. Ja mówię: «Czemu nie jesz, przecież ten rosół wystygnie?» [śmiech] A on nie wie, co ma robić - czy ma jeść, czy nie ma jeść. Setę wódy wlał do rosołu i teraz ma, nie? I on właśnie teraz, jak byłem na [niezrozumiałe], to on powiedział mi, że «Pan ze mnie zrobił człowieka», bo on przestał pić, ożenił się i ma dzieci i szczęśliwy jest, no... [śmiech] Taka satysfakcja była, prosta, ale... W każdym razie, ja mam w tych piłkarzy ciągle z... Arka to bez przerwy tam do mnie ci piłkarze dzwonili... [...] Bo tam, jak ja przyszedłem, to ta sitwa, która tam przede mną była, no to oni się zmobilizowali i chcieli mnie wyrzucić. No z gazety "[Głos] Wybrzeża” taki artykuł, że jakiś tam przyjechał i nasz sport ustawia i takie duperele tam napisali. / MŻ: A jeden dziennikarz, Tomasz Wotek napisat zupetnie co innego. Sprzeciwit się takiej prasowej nagonce. / Tak. Ten pisał świetnie. Nawet do mnie pisał jeszcze listy, wysyłał mi do Algierii ten dziennikarz. Takie... Zaprosił mnie do radia, mieliśmy tam wywiad, no bo jak prowadziłem drużynę, to takie rewolucji pouciekali tu, tamto... Ja stworzyłem drużynę, która weszła z powrotem ligi, wygrała tę konkurencję z Lechią, która była oczkiem całej tej plejady tych szefów. A tu nagle przyjechał jakiś i w ostatnim meczu wyłożył... Weszliśmy do pierwszej ligi z powrotem. Więc tu miałem takie chody i on powiedział: «No, pan ze mnie zrobił prawdziwego człowieka, bo mam żonę, mam dziecko, nie piję». Ja powiedziałem: «To najważniejsza rzecz, coś mi powiedział, że nie pijesz, no». [...] Tam w Gdyni miałem o tyle dobrze, że ci kibice to oni pilnowali, ja wszystko wiedziałem. Najlepsi to byli taksówkarze, bo oni dobrze wiedzieli, gdzie oni [piłkarzy] [śmiech] na te bankiety po meczu wywożą, no. I pierwsze co przyjeżdżał od razu i mówi: «Panie Stefanie, jedziemy». Pojechaliśmy gdzieś tam pod Władysławowo, jak wjechaliśmy tym samochodem, ja wysiadłem, no to ta cała sitwa, to akurat było lato, ciepło, okno pootwierane na parterze, a oni przez te okna wszystkie uciekali [śmiech]. Jak zobaczyłem... / MŻ: To były czasy, kiedy trener się tym przejmowat. Dzisiaj to trenerzy, to generalnie maja to gdzieś. / Kiedyś trener z nim tam [niezrozumiałe], no takie były układy. A potem to przecież oni nie kupowali butelkę wódki, tylko skrzynkę, wie pan. To było co pracować... Z takim człowiekiem to przecież człowiek nie zrobi żadnego wyniku. I potem oni doszli do głowy, czy im się opłaca. Bo ja im powiedziałem tak: «Za pierwszy wygrany mecz macie 50 zł». Co dla nich 50 zł było, nie? «Jak wygracie ten mecz, za drugi mecz to macie 100 zł». No to już lepiej... «Za trzeci macie 300 zł, za czwarty 500». No to oni wtedy zaczęli się już cholernie pilnować nawzajem. Jak ja odchodziłem, to każdy miał swoją książeczkę PKO, bo ja im pieniędzy nie dawałem, bo wiadomo było, że jeżeli on by dostał pieniądze z kasy i za 100 metrów nie miałby już pieniędzy, nie? Tacy niestety to byli piłkarze, no. To jak oni się pilnowali, żeby broń Boże... No. Tak że jak odchodziłem, to oni podostawali po 40, po 50 tysięcy mieli na książeczkach. / MŻ: Na tamte czasy to trochę byto... samochód kosztowat tyle. / Tak, a jeszcze dostawali za wejście do ligi talony na maluchy. Połowa Arki jeździła maluchami [śmiech]. No, bo dostali talony i pieniądze do tego. / MŻ: [19]76 rok...". 
No i w Arce, po roku, [w]prowadziłem z powrotem do pierwszej ligi. Tak, tam była dość taka wielka wojna z tą Lechią, Lechia - Arka ${ }^{61}$.

\section{Algieria}

I tymczasem Kazio Górski po tej Olimpiadzie w Kanadzie ${ }^{62}$ mówi: „Słuchaj, mamy tutaj zapotrzebowanie, jedziemy do Kuwejtu". I nawet podpisywaliśmy z tym przedstawicielem z Kuwejtu umowy. Kaziu tam jakichś... jeszcze $\mathrm{z}$ dwóch tam sobie [wziął trenerów] na drużyny te młodzieżowe. W każdym razie ja miałem wziąć seniorów, on był szefem tego związku trenerskiego, który miał jechać do Kuwejtu i jak przyjechaliśmy do Głównego Komitetu ${ }^{63}$, powiedział: „Żadnego Kuwejta nie będzie. Będziecie pracować w Polsce”. Kazio miał paszport [śmiech], bo był na tej Olimpiadzie w Kanadzie, i pojechał prosto do Grecji ${ }^{64}$. A ja [śmiech], że zostałem, w Arce [wcześniej] wypowiedziałem umowę, no bo grzecznie wypadało tak zrobić [przed wyjazdem], zostałem bez pracy i siedziałem w domu, czekałem, co będzie dalej. Tak siedziałem, ni stąd, ni zowąd przychodzi... Tam ja chodziłem do tego Głównego Komitetu, a oni mi ciągle, spychologia, jeden mówi: „Może do Związku Radzieckiego by pan pojechał?”. Ja mówię: „Bardzo chętnie, tylko jak oni płacą, nie?” [śmiech]. Takie były rozmowy, żeby mnie zepchnąć z tej ścieżki wyjazdu za granicę. Ale ni stąd, ni zowąd, dosłownie, dwa czy trzy dni przed Bożym Narodzeniem przychodzi z Głównego Komitetu telegram: „Zrobić świadectwo zdrowia i stawić się w Algierii" [śmiech]. To dopiero dla mnie była [niespodzianka], bo nie znam języka, nie znam tego... Zacząłem tam gmerać, szukać jakoś. Świadectwo zdrowia to nie był żaden problem zrobić. Mi zrobili błyskawicznie. Także dosłownie w Wigilię... Który to był rok? Pięćdziesiąty...

61 Chodzi o tzw. Derby Trójmiasta, czyli mecze pomiędzy Lechią Gdańsk i Arką Gdynia. Pierwszy taki pojedynek, poza towarzyskimi meczami, odbył się 2 IX 1964 r.; M. Średziński, 70 meczów na 7o-lecie gdańskiej Lechii, Gdańsk 2015, s. 48.

62 Chodzi o XXI Letnie Igrzyska Olimpijskie w Montrealu w 1976 r., które zakończyły się zdobyciem srebrnego medalu przez piłkarską reprezentację Polski pod wodzą Kazimierza Górskiego.

63 Chodzi o Główny Komitet Kultury Fizycznej, organ administracji PRL, zajmujący się sportem i turystyką.

64 O nieudanym wyjeździe do Kuwejtu zob.: K. Górski, S. Grzegorczyk, J. Lechowski, op. cit., s. 153-154. 
MŻ: Gdzie... gdzie rok [19]50...

W każdym razie wylądowałem...

MŻ: Siedemdziesiąty... [197]7, [197]8.

1976.

MŻ: [19]77 na [197]8.

Tak. Wylądowałem w Algierze ${ }^{65}$. A w Algierze zrobili rewolucję sportową. [...] Minister sportu zobowiązał wszystkie kluby do... że muszą zatrudnić trenera zagranicznego [śmiech]. I w każdym klubie w pewnym czasie tu rzeczywiście byli trenerzy zagraniczni. No między innymi było dwóch Czechów, ja, paru Rosjan. Taka mieszanina. Także Boże Narodzenie w tym czasie spędziliśmy międzynarodowo na tym stadionie Cinq Juillet, w tym w Algierze ${ }^{66}$. To niektórzy byli z rodzinami, a ja sam. I tak dostałem pracę w Algierii, gdzie przydzielili mnie oczywiście do drużyny, która była mistrzem Algierii. Jak ja zobaczyłem, to jak na mistrza, to oni mnie się nie podobali. I tak przyglądałem się tym treningom... A tym trenerem to był brat prezesa tego klubu. No to on, co on tam [śmiech]? Ci młodzi, ci piłkarze, którzy tam... Bo przede mną tam trenował Rumun i Jugosłowianin ${ }^{67}$. Więc oni zrobili, dzięki temu Jugosłowianinowi, mistrzostwo Algierii. Także on to prowadził nieźle, bo dobra drużynka, bo tam ci piłkarze afrykańscy to mają smykałkę do tej piłki. No i mnie wsadzili do tego mistrzowskiego [klubu].

SzB: Jak drużyna się nazywata?

To się nazywało Jeunesse Sport... JSK, no tak się nazywało, Jeunesse Sport de Kabylie ${ }^{68}$.

SzB: Zostat pan trenerem i co byto dalej?

65 Chodzi o stolicę Algierii.

66 Chodzi o stadion Stade 5 Juillet 1962 w Algierze.

67 Osoby bliżej nieznane.

68 Chodzi o drużynę Jeunesse Sport de Kabylie, która w momencie przyjazdu świadka do Algierii znana była pod nazwą JE Tizi-Ouzou. 
Nie no, zostałem przydzielony [do drużyny], tego, i tam był trener. No to ja przecież nie mogłem przyjść, powiedzieć... tym bardziej, że jego brat [śmiech] był prezesem tego klubu, to jak mogłem powiedzieć, żeby przestał trenować, bo on w ogóle nie trenował. Tam było tak dość ciekawie, bo oni mieli boisko w Tizi Ouzou nowe ${ }^{69}$, jeszcze nie oddane, [tam] trenowali. Na tym boisku dwa dni i potem dwa dni trenowali w Algierze. I to taka była wycieczka - dwa dni tu, dwa dni tam. I połowa zawodników mieszkała w Algierze, połowa mieszkała tam. No przecież to nie można było w ogóle zacząć w ten sposób pracę. Tak się przyglądałem, jak to wszystko [się] dzieje. W końcu było zebranie z prezesem tego klubu i powiedziałem: „Od jutra zaczynamy, ja zaczynam treningi”. Ten młody trener, brat tego prezesa, no on był wielki ten, ale się zgodził. I ja zacząłem treningi, a on się tylko przyglądał [śmiech] i trenował bramkarzy, co było najlepsza dla niego robota ${ }^{70}$. I tak mi przyszło do głowy, ponieważ z Arką ja byłem w bardzo dobrej komitywie $^{71}$, a oni mi, jako mistrzowie Algierii, grali w mistrzostwach Afry$\mathrm{ki}^{72}$. Więc te całe przygotowanie do tego meczu mistrzowskiego w Afryce, to tam były nakłady i wszystko. Minister sportu naciskał, bo oni tam mieli wielkie ambicje, i żeby przygotowywać zespół. Przyszło mi do głowy, gdzie pojadę - do Francji nie, bo ja nie znam języka francuskiego [śmiech]. I wymyśliłem sobie, zadzwoniłem do Arki, ten prezes bardzo dobry [był], lubiał zresztą mnie, i powiedział: „No dobra” i zdecydował się, że on przyjmie mnie na obóz do Gdyni. I ja przyjechałem, oni mnie wsadzili, no zgodzili się na ten obóz. No i ja w rewanżu, znaczy my, przyjmiemy tę Arkę w Algierii. Taka była umowa. Mnie wsadzili do domu dla tego... Tam w ogóle dzieci, tam domy były rodzinne jakieś, ale „Bałtyk” akurat odnowiony hotel

69 Tizi Ouzou (Tizi Wuzu), miasto w północnej Algierii, w regionie Kabylia, zamieszkane głównie przez ludność pochodzenia berberyjskiego.

70 Świadek o treningach w Algierii mówił także w drugiej części wywiadu: „Najgorzej to tam, wie pan, jak jest ten ramadan, to tam jest ten post i to jest wszystko odwrócone. Czyli w dzień się nic nie je, nie pije, tylko w nocy. No i moi piłkarze, to są nauczeni, nie? Tylko słońce zaszło, to już jedzenie było jak trzeba. No i co dalej? To ja im zrobiłem [niezrozumiate] «zjedzcie szybko i o godzinie dwunastej w nocy jesteście na stadionie» [śmiech]. I to co oni zjedli o 8 wieczór, to oni musieli w nocy... [śmiech] Trochę się tam bruździli, a ja mówię: «Ale jak wygrasz mecz, to kasę chcesz brać, nie? Premię dostajesz, to skąd ta premia ma ci się brać? To musisz zarobić, no»”.

71 Chodzi o klub Arka Gdynia.

72 Chodzi o Afrykańską Ligę Mistrzów. 
oddał $^{73}$. Ja do jednego mówię: „No stary, gdzieś [jak] ja tutaj mogę [z] zawodnikami odpoczywać, dwa razy dziennie trening i przychodzisz, [a] tu dzieci biegają to tam... Z jedzeniem problemy...", bo tam takie kolejki wtedy były, straszna sprawa [śmiech]. No, ale poszedłem do tego prezesa, od tego „Bałtyku” i mówię: „Pan to wynajmie ten lokal?” Bo oni oddali hotel i jeszcze nie niezamieszkały [był]. A on mówi: „Dobra, ale co ja będę z tego miał?”. To ja mówię: „No to tu będziemy ile, dziesięć dni. I pana zaprosimy do Algieru”. I on się zgodził, bo on lubiał turystykę, ten dyrektor tego "Bałtyku”. I w ten sposób trenowałem w „Bałtyku”, mieszkałem tam w „Bałtyku” i zrobiłem przygotowania do sezonu bardzo dobre. Myśmy grali dobre mecze tam, bo tam na Wybrzeżu było gdzie z kim pograć. Przyjechaliśmy do Algieru. No i teraz mamy ten pierwszy mecz do eliminacji, bo to w grupach tam były [najpierw] te rozgrywki. Taki pierwszy mecz, co miałem w Algierze, do przerwy myśmy prowadzili 3:o. Czyli drużyna była na takim chodzie, że to za mało było 3:0. Zniszczyliśmy tego przeciwnika ${ }^{74}$, ale to tylko do przerwy. Po przerwie, ten mój środkowy obrońca... on sobie ubrał nowe buty na mecz [śmiech]... Także on tę drugą połowę to już nie mógł biegać, tylko chodził. Drugi też taki był student, co filozofował, i ni stąd, ni zowąd piłka szła do bramki, a on zrobił karnego ${ }^{75}$, 3:2. I skończyliśmy ten mecz na 3:2. Oni jeszcze pod koniec strzelili 3:3, z 3:0... [...] Tak to było, wie pan... Kurde, jaki byłem wściekły na tych wszystkich. No, jak pojechaliśmy na rewanż do tego Sudanu, no to tam nie było żadnych szans ${ }^{76}$, bo ten sędzia pierwsze co, od razu ze spalonego strzelili nam pierwszą bramkę, 1:o u siebie, 3:3 na wyjeździe i do widzenia. I skończyła się taka moja wojna, w pierwszą tę afrykańską rozgrywkę w piłce nożnej.

73 Chodzi prawdopodobnie o wybudowany w latach 7o. XX w. Hotel Bałtyk w Gdyni.

74 Być może chodzi o rozgrywki Afrykańskiej Ligi Mistrzów w 1978 r., kiedy to JE Tizi-Ouzou odpadło w 1/4 finału, po meczu z drużyną z Kinszasy; zob.: Rec. Sport.Soccer Statistics Foundation, http://www.rsssf.com/tablesa/afcup78.html (dostęp: 12 II 2019 r.).

75 Chodzi o to, że zawodnik złamał przepisy gry, co spowodowało podyktowanie przez sędziego rzutu karnego dla przeciwnej drużyny.

76 Być może chodzi jednak o wyprawę do Zairu, zob. przypis 74 . 
No, jak ja przyjechałem z powrotem, to wtedy zrobiłem po prostu piłkarską rewolucję. A już przygotowywałem sobie młodych zawodników. Tam miałem paru takich juniorków, wie pan, klasa. Oni trzymali tych po trzydzieści parę lat [śmiech], starych piłkarzy, bo to sitwa się tam trzymała. No to ja wtedy ich rozgoniłem. Tym wszystkim starym powiedziałem do widzenia i wziąłem się za tą młodzież. I tą młodzieżą zacząłem jechać. To była drużyna, z którą zdobyłem siedem razy mistrzostwo Algierii, w tym jeszcze dodatkowo dwa finały pucharu Algierii ${ }^{77}$. No to drużyna naprawdę zaczęła być wielka. No i zaczęło się znowu, tamten wyjedzie, tamten wyjedzie, tamten wyjedzie. To ja mówię: „No to po co ja jestem wam tu potrzebny, jak będziecie sprzedawać [zawodników]?”. I poszedłem do tego ministra, to był minister, który był właściwie lekarzem ${ }^{78}$. A jego zrobili ministrem sportu, ale on mnie polubił bardzo, i ja poszedłem do niego. On od razu: „Zakaz, żaden Algierczyk nie wyjeżdża za granicę". I tak utrzymałem tę drużynę i zrobiłem siedem razy mistrzostwo Algierii, dwa puchary i dwa mistrzostwa Afryki ${ }^{79}$. Bo oprócz tego, że ja pracowałem z seniorami, to jeszcze raz w tygodniu miałem zajęcia z tymi piłkarzami młodymi, najlepszymi juniorami. I potem ta najlepsza grupa tych juniorów stała się seniorami w tej drużynie. Także oni już mój program prze[trenowali], tak jak trzeba było.

\section{MŻ: Przez czternaście lat to trzy pokolenia.}

Także wtedy nie było żadnego problemu i gdzie tylko pojechaliśmy, tam wygrywaliśmy. Tak zrobiłem właśnie, no. Dostałem odznaczenie od samego prezydenta Algierii ${ }^{80}$. Także... przyjął nas po pierwszym zdobyciu tego mistrzostwa, przyjął nas u siebie w gabinecie, tego. Zawodnicy podostawali tam te premie, nie premie, tego. No, a ja dostałem państwowe odznaczenie,

77 JE Tizi Ouzou (JS Kabylie), gdy Żywotko był trenerem, wygrało dwukrotnie Afrykańską Ligę Mistrzów (1981 i 1990 r.), sięgnęło po mistrzostwo kraju w 1980, 1982, 1983, 1985, 1986, 1989 i 1990 r. oraz po puchar kraju w 1986 r.; zob.: Rec.Sport.Soccer Statistics Foundation, www.rsssf.com (dostęp: 13 II 2019 r.).

78 Osoba bliżej nieznana.

79 Chodzi kolejno o mistrzostwo ligi algierskiej, puchar Algierii i Afrykańską Ligę Mistrzów, zob. przypis 77.

80 Chodzi o prezydenta Algierii Chadli Bendjedida (1979-1992). 

piętnaście lat ${ }^{81}$.

MŻ: Wtaściwie powiedzieli, że niech ojciec już stamtad nie wyjedzie, że już będzie tam, zostanie. No, ale wojna wybuchta.

I jeszcze do tego, tam zaczęła się już tamta, wewnętrzna ich rewolucja ${ }^{82}$, to nie było już roboty. Trudno było jechać [przez kraj] nawet, jak oni [rewolucjoniści] potrafili zatrzymać autobus i powyciągać, i niektórych to postrzelać nawet. To była masakra, no. To trzeba było po prostu uciekać i wyjechaliśmy, i wyjechałem...

SzB: Wrócit pan do Szczecina, tak?

Do Szczecina, a gdzie?

SzB: Mhm. I jak dalsze losy, już po powrocie z Algierii, się uktadały panu?

Losy algierskie?

SzB: Znaczy jak już pan wrócit z Algierii, bo tam w Algierii byty zmiany polityczne, byto niebezpiecznie, tak?

No tak, no to jak ja wróciłem, to ja zrobiłem z nimi drugi raz mistrzostwo Afryki ${ }^{83}$. Najlepsze, co można było, nie? [śmiech]. Mistrza Afryki, nie...?

81 Stefan Żywotko był trenerem JE Tizi-Ouzou (JS Kabylie) w latach 1977-1991; FootballDataBase.eu, www.footballdatabase.eu/en/player/details/122406-stefanzywotko (dostęp: 13 II 2019 r.).

82 Chodzi o wojnę domową w Algierii, w której islamscy fundamentaliści wystąpili przeciwko algierskiemu rządowi. Konflikt miał miejsce w latach 1992-200o, ale już wcześniej dostrzegalny był wzrost siły fundamentalistów, a w 1991 r. dochodziło do licznych manifestacji islamistów; A. Kasznik-Christian, Algieria, Warszawa 2006, s. 454-500.

83 Doszło tutaj prawdopodobnie do niezrozumienia na linii rozmówca - badacz. Zarówno poprzednie fragmenty relacji, jak i serwisy z piłkarskimi statystykami nie wskazują, żeby świadek opuścił JS Kabylie, a następnie wrócił i ponownie prowadził ten zespół. Stefan Żywotko był trenerem algierskiego klubu nieprzerwanie, w latach 1977-1991. Może chodzić o wspomniany wyżej powrót z drużyną po zgrupowaniu w Gdyni, zob.: FootballDataBase.eu, www.footballdatabase.eu/en/player/ details/122406-stefan-zywotko (dostęp: 13 II 2019 r.). 
Ja jak byłem z synem tam [w Algierii], w odwiedziny, bo zapłacono [za] samolot, wszystko, żebym ja przyjechał. [...] No i jak przyjechałem w [19]81 r., to oni chcieli, żebym ja podpisał z nimi umowę, naprawdę, no [śmiech]. Ja już miałem 80 lat, a oni jeszcze chcieli, żebym ja trenował, no ${ }^{84}$. A teraz, niezależnie od wszystkiego, dwa tygodnie temu to dwa telefony miałem z Algierii. Oni [JS Kabylie] rozpaczają, bo oni są tam na trzynastym, czternastym miejscu, grozi im spadek ${ }^{85}$. To ja mówię: „Przecież nie pojadę do was, was trenować w tej chwili”. A oni tam wybrali takiego prezesa, który patrzył się tylko, żeby zarobić na tym sporcie, a nie żeby, zrobić... [...] Bo tam na przykład była taka... Myśmy mieli tam ten stadion, który miał płyty [ze] sztuczną, sztucznej trawy... I tam postanowili wybudować nowy stadion. I to w dobrym miejscu, bo była skarpa od razu na te trybuny. No to ten prezes ${ }^{86}$, pierwsze co zrobil, to wyciął drzewa tam, bo tam tamten las był, nie? [śmiech] I to drzewo, to było warte bardzo kupę forsy.

\section{MŻ: Sprzedat.}

No. [śmiech]

\section{MŻ: I skończyt budowę stadionu... [śmiech]}

I on zaczął pracę nad budową stadionu właśnie w ten sposób, że wyciął drzewa i sobie to [drzewo] zabrał [śmiech]. No, bo jak ciął, to dla siebie. I nic nie zrobili. Jak ja pojechałem drugi raz, to tam nędza. I oni w tej chwili ciągle na niego [tego prezesa] narzekają, go wyrzucili w tym roku.

84 W roku 1981 r. Stefan Żywotko miał 61 lat i był trenerem JS Kabylie, prawdopodobnie chodzi tu o lata późniejsze, już po powrocie do Polski i przejściu na emeryturę.

85 W momencie nagrywania relacji trwał piłkarski sezon 2017/2018 pierwszej ligi algierskiej, a drużynie JS Kabylie groził spadek. Ostatecznie zespół zajął jedenaste miejsce i utrzymał się w rozgrywkach.

86 Osoba bliżej nieznana. 
MŻ: To byt obrońca środkowy.

Mój były zawodnik, właśnie ten, który pierwszy buty nowe ubrał na [mecz] [śmiech].

MŻ: Ale niezty byt jako zawodnik. Oni go...

Zawodnik był bardzo dobry. Twarda, siekiera taka i dobra głowa. Tylko słaby rozum miał.

MŻ: No nie taki staby, bo do...

No do pieniędzy to...

MŻ: Niezły miat [śmiech].

Do pieniędzy to on miał tam, dziesiątą klepkę bodajże [śmiech].

MŻ: Nie no, on tam miat wiele biznesów. Stacje benzynowe, sklepy...

Stację benzynową mu dali, wszystko. Także on tam robił niesamowite pieniądze.

MŻ: Firmę budowlaną.

Wybudował sobie kamienicę tu, tam domy. No, ale ja się do tego nie mieszałem, bo to mnie płacili tyle, ile miałem w umowie, koniec. I tak skończyłem w Algierii tylko dlatego, że tam się zaczęła ta wojna. Nie można było zostać, mówię [do] tego mojego kolegi, tego młodego trenera, jego brat był szefem służb jakichś tam, pułkownik ${ }^{87}$. No to jak on już wracał do domu z obstawą, to jego całą rodzinę i jego [samego] wystrzelali ci przeciwnicy, bo tam... no niesamowicie. Zatrzymali go pod domem, wszystkich postrzelali, w tym... 
Niesamowicie tam się działo. Tam trzeba było stamtąd uciekać jak najbardziej. Tak jak mówiłem, jedzie pan autobusem na mecz, zatrzymują w lesie pana, wszystkich po kolei wyciągają. W łeb.

MŻ: Co tam $100 \mathrm{~km}$ mniej więcej, $106 \mathrm{~km}$ i tam po drodze...

Niesamowite.

MŻ: Takie różne miejscowości jak u nas się jedzie, nie? To tam niektóre byty wymordowani wszyscy, nie? Nikt nie zostat, cate wioski byty wycięte.

Ten region, gdzie te Kabylie, kabylski, to on był spokojny, bo oni mieli własną, swoją armię zrobili, i ci, co tam jeździli, mordowali, to oni nie mogli dojść, bo oni wszyscy byli uzbrojeni, straszna wojna. [...] Także tam się oni uchowali jako tako, jeżeli chodzi o ten przewrót tam w Algierii, nie?

SzB: I co byto dalej? Jak zrobito się niebezpiecznie w Algierii to...

To było wszędzie niebezpiecznie, przyjechaliśmy z rodziną, z żoną tutaj do Szczecina i na tym koniec, no. Co miałem robić dalej? Do pracy...

MŻ: 71 lat, już emerytura.

No nie, ale to nieciekawie to się wszystko działo. [...] Poszedłem na emeryturę, dostałem [śmiech] państwową emeryturę i zostałem emerytem, no ${ }^{88}$.

88 W trzeciej części wywiadu Stefan Żywotko podsumował swoje osiągnięcia i skonfrontował je z pamięcią o swojej postaci: „A jeżeli chodzi o moje osiągnięcia, no to wiadomo, że dwa tytuły jak się zdobyło, to tak jak tutaj ja mówię, w Europie, to trąbią na wszystkie strony, a tu nawet w Szczecinie nikt nie wie, kim ja jestem [śmiech]. A jak ja oglądnę to wszystko, siedem razy być mistrzem kraju, w tym jeszcze dodaję dwa puchary bardzo ważne, to ważniejsze jak mistrzostwo. No i dwa razy być mistrzem tego kontynentu, bo to nie było łatwo. No to mnie tutaj by, powiedzmy gdybym ja tu zrobił w jakimś tam europejskim kraju, to by mnie na rękach nosili, a tutaj nikt nie wie, że taki trener, co tutaj Pogoń trenował przez pięć lat i budował w ogóle piłkę nożną w Szczecinie, istnieje. I sprawdzają, czy ja mam kartę wstępu na 
to boisko [śmiech]. Takie są czasy, ludzka pamięć to jest właśnie taka, że się pamięta coś, a później nie pamięta, ale wiem tylko tyle, że ci, z którymi ja pracowałem, oni mnie doskonale pamiętają. I to mnie tam na przykład zaskoczyło, że oni przysłali mi kwiaty i ten nie mógł się do nas dostać, ten kwiaciarz i był zły. Ja słyszę: «Mam tu dla pana tutaj jakieś te...». Zostawił mi awizo, że coś mam do odebrania. Ja mówię: «Gdzie on... kto mnie mógł dać?» No i w końcu on mnie złapał, patrzę, a on przywozi taki ogromny bukiet kwiatów w wazonie i z podpisami zawodników [z] lat [19]6o. Nie trzeba nic piękniejszego".

\section{Bibliografia}

Beniuk Sz., O pitkarskich trybunach Lwowa lat 3o. XX wieku na tamach prasy sportowej. Wybrane kwestie, „Prace Naukowe Akademii im. Jana Długosza w Częstochowie. Kultura Fizyczna”, t. 17 (2018), nr 1, s. 23-56.

Filipkowski P., O relacjach byłych więźniów kacetów w kontekście czasu, miejsca i sytuacji ich powstania (albo o pożytkach z historii mówionej), „Wrocławski Rocznik Historii Mówionej”, R. 2 (2012), s. 37-70.

Giergiel C., 70 lat historii Arkonii Szczecin, Szczecin 2016.

Goksiński J., Klubowa historia polskiej piłki nożnej do 1939 r., [w:] Regiony-branże-frekwencja, t. 1, Warszawa 2013.

Gowarzewski A., Encyklopedia pitkarska FUJI. Mistrzostwa Polski. Ludzie 1918-1939, t. 51, Katowice 2017.

Gowarzewski A., Encyklopedia piłkarska FUJI. Mistrzostwa Polski. Ludzie 1945-1962, t. 53, Katowice 2017.

Gowarzewski A., Wilno i Lwów w ekstraklasie, Katowice 1997.

Górski K., Grzegorczyk S., Lechowski J., Sekrety trenera Górskiego, Warszawa 1992.

Kasznik-Christian A., Algieria, Warszawa 2006.

Maciejewski T., Stefan Żywotko: Poganiaczem zostałem w Szczecinie, „Szczecin.Wyborcza.pl”, z 24 IV 2011 r., http://szczecin.wyborcza.pl/szczecin/1,34939,9487642,Stefan_Zywotko_Poganiaczem_zostalem_w_Szczecinie.html (dostęp: 18 III 2019 r.).

Mazur G., Życie polityczne polskiego Lwowa, Kraków 2007.

Niesamowite przygody Stefana Żywotki (wywiad przeprowadził Tomasz Zieliński), „Weszło. com", z 16 V 2015 r., http://weszlo.com/2015/o5/16/niesamowite-przygody-stefana-zywotki/ (dostęp: 18 III 2019 r.). 
Ordyłowski M., Rozwój kultury fizycznej na Ziemiach Odzyskanych w pierwszych latach po II wojnie światowej, [w:] Z dziejów sportu na Ziemiach Zachodnich i Północnych Polski po II wojnie światowej, red. J. Maliniak, P. Sroka, G. Strauchold, Wrocław 2014, s. 9-16.

Otałęga J., Za lotem piłki, Kraków 2003.

Podhorodecki L., Dzieje Lwowa, Warszawa 1993.

Poznaj nasze miasto. Przewodnik po Lwowie, Lwów 1933.

Rak L., Infrastruktura sportowa i działalność organizacyjna I Lwowskiego Klubu Sportowego Czarni w świetle lokalnej prasy (1920-1939), „Rozprawy Naukowe AWF we Wrocławiu”, nr 61 (2018), s. 98-110.

Schleyen K., Lwowskie gawędy, Łomianki 2002.

Stefanik R., Futbol w cieniu komitetów. Piłka nożna a władza w województwie szczecińskim w latach 1945-1989, Szczecin 2016.

Szolginia W., Tamten Lwów, [w:] Życie miasta, t. 5, Wrocław 1994.

Średziński M., 70 meczów na 7o-lecie gdańskiej Lechii, Gdańsk 2015.

The Tinned Food Factory of Zygmunt Rucker. A history of Polish business succesful formation, lia. LvivCenter.org/en/organizations/17-fabryka-rukera/ (dostęp: 18 III 2019 r.).

Ufland K. [et al.], 70 niezwyktych historii na 7o-lecie Pogoni Szczecin, Szczecin 2018. 
Szymon Beniuk
Stefan Żywotko's oral history account is a story about almost one hundred years of Polish history from the perspective of a person who was a football player and coach. His account includes, among others, the themes of the interwar Lviv, the World War II, post-war Szczecin, the beginnings of football in Western Poland, and a story about Algeria in the 1970 s and 1980 s. It is also an interesting source about this person, who has been very successful in sport but is not widely known in Poland.

Keywords: oral history account, sport life, football, Lviv, Szczecin, Arkonia, Pogon, Warta, Arka, Algeria, Kabylie, Tizi Ouzou 